\title{
Application of Social Multiliteration Model with Lesson Study Setting to Improve Critical Thinking Ability In the Elementary Social Studies Education Course
}

\author{
I Wayan Sujana ${ }^{1}$, Ni Wayan Suniasih ${ }^{2}$, I Ketut Adnyana Putra ${ }^{3}$ \\ \{iwayan.sujana@undiksha.ac.id ${ }^{1}$,niwayan.suniasih@undiksha.ac.id ${ }^{2}$, \\ ketut.adnyana.putra@undiksha.ac.id $\left.{ }^{3}\right\}$ \\ ${ }^{1,2,3}$ Universitas Pendidikan Ganesha, Indonesia
}

\begin{abstract}
This study aims to improve the critical thinking skills students in learning elementary social studies education through the application of a social multiliteration model. The subjects of this study were 69 PGSD students. The research which is a classroom action research (CAR) was conducted using the lesson study cycle. Test and observation were used to collect data. The data collected were analyzed using the quantitative descriptive techniques. The Results were obtained from the pre-cycle stage with an average was 67.61. The increase occurred in the first cycle with an average of 76.05. In the second cycle there was also a significant increase which resulted to an average of 87.56. Based on these results, it can be concluded that the application of the social multiliteration model with lesson study setting can enhance critical thinking skills when teaching elementary social studiess education course in elementary schools.
\end{abstract}

Keywords: social multiliteration, critical thinking, social studies.

\section{Introduction}

Teachers and students opting to be teachers are expected to study hard in order to prepare themselves to be creative and open minded during the course of their profession. Professional teachers are expected to be competence, professional, social, and personable. According to Danim, "collaboration includes all activities that brings members, communities, schools, and external supporters together to share information, ideas, and decisions, for the betterment of the institution ".[1] It also involves building competencies that would be able to teach students opting to be teachers, to understand the components curriculum, strategy, model, media, and evaluation learning strategies.

Elementary Social Studies Education is one of the lectures programmed to teach second semester PGSD students the concepts, facts, and generalization needed to learn geography, economics, history, sociology, anthropology, science politics, and psychology. Related to the social science, the elementary social studies is classified as an integrated social (integrated IPS). Furthermore, the material is designated to meet the social interests of students at the elementary schools through the expansion approach. 
In the previous learning technique, teachers' candidates utilize the sources of the learning in form of graphic media.However, it can be said that students' creativity in utilizing the media is not yet optimal. The utilization sources in learning could not be ascertained regardless of the strategies, approaches, models and methods applied by the educator. Abidin[2]declared a suitable multiliteration model intended to enhance the understanding concept through social activities such as reading, writing, and oral technology. IPS elementary school studying concepts, facts, and generalization in the physical, social and cultural environment is relevant enough if learned through multiliteration models. By using this model, teachers are directed for review social problems related to their curriculum using relevant teaching materials, so that college students are able to analyze facts, discover and organize ideas, maintain opinion, make comparison, interesting conclusions, and evaluate argument (Chanche, in Huitt[3]). Implementation learning has a lot to offer to college students through discovery, and mastery of materials (concept and fact). Based on implementation curriculum many carry out constructivist pattern thinking. This could be applied through the ability to reason critically when preparing college for the teaching quest ahead.

\section{Method}

The implementation research method in the form of classroom action research (CAR) was used during this lesson study. It comprises of four stages, namely planning, implementation, observation, and evaluation and reflection. The activity is described in detail as follows.

\subsection{Planning}

This stage begins with a permit application carried out at the University of Pendidikan Ganesha in a bid to continue the research initially carried out at UPP Denpasar PGSD. After obtaining permission, data was collected and analyze to dertermine the best course of actions to be taken. The test was conducted using a rubric assessment that is in accordance with the rubric of critical thinking skills.

\subsection{Implementation}

The implementation is carried out with learning techniques in accordance with the plans for implementing lectures by applying the multi-literacy model. These lectures were conducted by providing related learning case studies needed by the program implementing team in charge. After being guided by the theory and the initial study of the team, the students who are the target subjects are trained, guided and facilitated on how to develop critical thinking skills.

\subsection{Observations}


In the observation activity, the team analyzed all the activities related to students' critical thinking skills.

\subsection{Evaluation and Reflection}

To evaluate and analyze students' thinking ability level, tests are carried out in each cycle. Then the test results were analyzed using descriptive analysis. Reflection is carried out with the aim of improving certain parts such as students' weaknesses in applying critical thinking skills.

Datasets from his research can be accessed from https://osf.io/zek7c/[4] from the Open Science Frameworks.

\section{Results and Discussion}

The implementation of this research activity, involving 69 students reached $100 \%$ when critical thinking skills were applied in elementary school social studies courses, activities from the results achieved in conducting research is presented in the following table.

Table 1. Results of analysis of research implementation

\begin{tabular}{cccc}
\hline Analysis & Pre-cycle & $\begin{array}{c}\text { Stage } \\
\text { Cycle I }\end{array}$ & Cycle II \\
Total value & 4665 & 5247.5 & 6041.5 \\
Average & 67.61 & 76.05 & 87.56 \\
The highest score & 80 & 90 & 94 \\
The lowest score & 45 & 47.5 & 70 \\
Average Percentage & $67.61 \%$ & $76.05 \%$ & $87.56 \%$ \\
Mode & 70 & 80 & 88 \\
Median & 70 & 77.5 & 88 \\
\hline
\end{tabular}




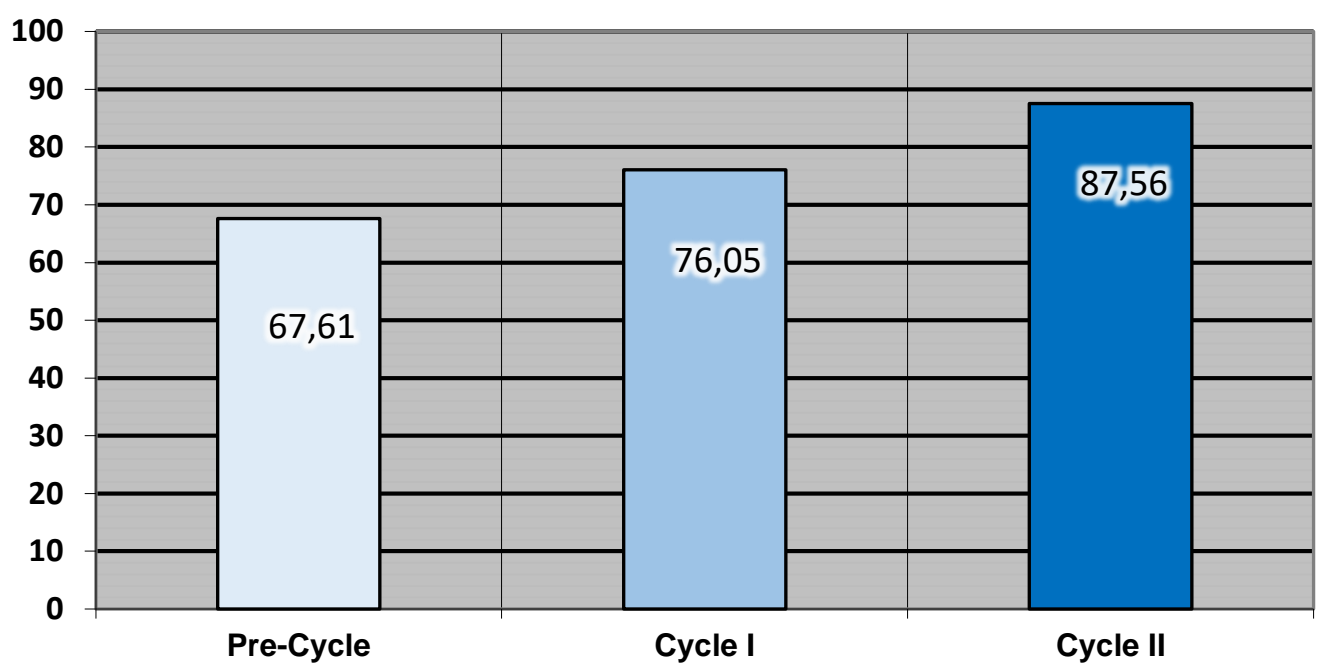

Fg.1. Graph of data on students' critical thinking skills with the application of multiliteration learning.

From the research, it can be analyzed that the data obtained through the application of multiliteration learning study shows the results of critical thinking skills in elementary social studies education courses students Semester II PGSD Undiksha UPP Denpasar.

The results of this study are evidenced by the increase in the results of the average critical thinking skills of students as measured by the assessment rubric sheet. At the pre-cycle stage, the average student's critical thinking ability was only 67.61 ( medium category) which indicated that at this stage students only used few and less developed learning resources, which resulted in a limited ability to criticize problems in the first cycle, the research subjects was developed, and understood from the social multiliteration learning model that utilizes all types of learning models, both from the virtual world, library studies, and the surrounding environment. So that at the end stage of the first cycle there was a positive increase, with an average of 76.05. But this increase is not significant and still high though it hasn't reached the agreed category. This continued and improved in the second cycle based on input, suggestions and constructive criticism from colleagues, lecturers, and research subjects who took part in the research.

The second cycle shows the results of a significant positive increase with the average results reaching 87.56. These results indicate that the research subjects (students) understood that learning forms critical thinking skills through experiences by the research subjects (students).

The research on militarization has been carried out by Dafit[5] with a 18.76 the average post-test score of the experimental class, while the average score of the post-test of the control class students is 16.04. The results of the writing shows that the multiliteration learning model has an influence on the reading ability of elementary students. 
The same thing was stated by Untari[6] who concluded that multiliteration learning needs to be applied to PGSD students so that students have the ability to to carry out learning implementation in line with the 2013 curriculum.

\section{Conclusion}

Based on these results of the research and analysis, it can be concluded that the application of social multiliteration model with the lesson study setting can improve critical thinking skills in elementary school social studies courses, in students of the Undiksha UPP Denpasar

\section{Reference}

[1] S. Danim.: Pengembangan Profesi Guru. Jakarta: Prenanda Media Grup (2011)

[2] Y. Abidin.: Pembelajaran Multiliterasi. Bandung: Refika Aditama (2015)

[3] W. Huitt.: Critical Thinking: An Overview. Educational Psychology Interactive. Valdosta, GA: Valdosta State University (1998)

[4] I. W. Sujana.: "Datasets of " Application of Social Multiliteration Model with Lesson Study Setting to Improve Critical Thinking Ability In the Elementary Social Studies Education Course, 2019. [Online]. Available: https://osf.io/zek7c/.

[5] F. Dafit.: Pengaruh Model Pembelajaran Multiliterasi Terhadap Kemampuan Membaca Siswa Sekolah Dasar.," J. Inov. Pendidik. dan Pembelajaran Sekol. dasar, vol. 1, no. 1 (2017)

[6] E. Untari.: Pentingnya Pembelajaran Multiliterasi Untuk Mahasiswa Pendidikan Guru Sekolah Dasar Dalam Mempersiapkan Diri Menghadapi Kurikulum 2013," J. Inov. Pendidik. dan Pembelajaran (2017) 